\title{
PENGARUH CONTEXTUAL TEACHING AND LEARNING (CTL) TERHADAP PRESTASI SISWA PADA BIDANG STUDI PAI DI SDIT INSANTAMA BANJAR
}

\author{
Fajar Farham Hikam ${ }^{1} \&$ Salma Karima ${ }^{2}$ \\ STIT NU Al-Farabi Pangandaran ${ }^{1}$, HSG Rumah Tahfidz Ar-Rahman ${ }^{2}$ \\ farhan.hikam@gmail.com
}

\begin{abstract}
The purpose of this study was to determine how much influence the Contextual Teaching and Learning (CTL) learning method has on student achievement in the field of Islamic Religious Education (PAI), this implementation was carried out at SDIT Insantama Banjar. With this it is identified that the Contextual Teaching and Learning (CTL) learning method is named as the X variable while the PAI learning achievement is named as the $Y$ variable. This research is a correlation study with a quantitative approach with a population of 23 people all of which are used as research samples. Based on data processing, that there is a significant effect of the CTL learning method on student achievement with the regression equation $Y=10,412+1,705 X$. The results of the correlation coefficient or the relationship turned out to show a significant relationship between the two variables studied, the coefficient and correlation values obtained Contextual Teaching and Learning (CTL) learning methods with learning achievements in the field of Islamic Religious Education (PAI). Contextual Teaching and Learning (CTL) learning methods bave a strong influence on student achievement.
\end{abstract}

Keywords: Contextual Teaching and Learning, Learning Achievement, Learning Method

\begin{abstract}
Abstrak: Tujuan penelitian ini adalah untuk mengetahui seberapa besar pengaruh metode pembelajaran Contextual Teaching and Learning (CTL) terhadap prestasi siswa terhadap bidang stadi Pendidikan Agama Islam, pelaksanaan ini dilaksanakan di SDIT Insantama Banjar. Dengan ini di identifikasikan bahwa metode pembelajaran Contextual Teaching and Learning (CTL) dinamakan sebagai variabel X sedangkan prestasi belajar PAI dinamakan sebagai variabel Y. Penelitian ini merupakan penelitian korelasi dengan pendekatan kuantitatif dengan populasi 23 orang yang semuanya dijadikan sampel penelitian. Berdasarkan pengolahan data, bahwa terdapat pengaruh yang signifikan metode pembelajaran CTL terhadap prestasi belajar siswa dengan persamaan regresi $\mathrm{Y}=10.412+$ $1.705 \mathrm{X}$. Hasil penelitian koefisien korelasi atau hubungan ternyata menunjukan adanya hubungan yang signifikan antara kedua variabel yang diteliti, diperoleh harga koefisien dan korelasi antara metode pembelajaran Contextual Teaching and Learning (CTL) dengan prestasi belajar bidang studi Pendidikan Agama Islam (PAI). Metode pembelajaran Contextual Teaching and Learning (CTL) mempunyai pengaruh yang kuat terhadap prestasi belajar siswa.
\end{abstract}

Kata Kunci: Contextual Teaching and Learning, Prestasi Belajar, Metode Pembelajaran

Fondatia : Jurnal Pendidikan Dasar

Volume 4, Nomor 2, September 2020; 187-204

https://ejournal.stitpn.ac.id/index.php/fondatia 


\section{PENDAHULUAN}

Pendidikan pada hakekatnya merupakan unsur vital dalam kehidupan dan merupakan kebutuhan serta tuntutan yang sangat penting untuk menjamin perkembangan, kelangsungan kehidupan berbangsa dan bernegara. Perkembangan dan kelangsungan suatu bangsa dan negara lebih tergantung pada kualitas sumber daya manusianya bukan sumber daya alamnya. Kualitas yang dikehendaki itu lebih tergantung pula dari keberhasilan penyelenggaraan sistem pendidikannya.

Keberhasilan penyelenggaraan pendidikan tidak hanya sekedar transfer of knowledge saja, tetapi lebih pada pembentukan kepribadian seseorang sehingga dapat mengenal potensi diri dan selanjutnya dapat mengembangkan potensinya sebagai suatu usaha untuk mencapai tujuan hidupnya.

Dalam konteks Pendidikan Agama Islam, mempunyai kualifikasi sendiri dalam memberikan kejelasan konseptual dari makna pendidikan, pembentukan pribadi yang dimaksud adalah kepribadian muslim dan kemajuan masyarakat serta budaya yang tidak menyimpang dari nilai-nilai ajaran Islam. Pendidikan Agama Islam merupakan proses transformasi dan realisasi nilai-nilai ajaran Islam melalui pembelajaran, baik formal maupun non formal kepada masyarakat (peserta didik) untuk dihayati, dipahami serta diamalkan dalam kehidupan sehari-hari dalam rangka menyiapkan dan membimbing serta mengarahkan agar nantinya mampu melaksanakan tugas kekhalifahan di muka bumi dengan sebaik-baiknya.

Untuk membentuk kepribadian muslim atau insan kamil seperti apa yang menjadi tujuan Pendidikan Agama Islam tentunya membutuhkan figur yang representatif untuk dijadikan acuan dalam mencapai tujuan tersebut. Beliau adalah Rasulullah Saw. Hampir setiap perbuatan yang dilakukannya selalu terjaga mutunya, sholat beliau adalah sholat yang khusu' yang bermutu tinggi dan amal-amal yang ikhlas serta terpelihara kualitasnya. Demikian juga keberaniannya, tafakkurnya dan aneka kiprah hidup sehari-hari beliau yang seluruhnya senantiasa dijaga untuk menghasilkan kualitas tertinggi. Beliau adalah pribadi sangat menjaga prestasi dan mempertahankan kualitas terbaik dari apa yang sanggup dilakukannya. Tidak heran 
kalau Allah SWT. Menegaskan dalam surat al-Ahzab ayat 21 yang terjemahnya sebagai berikut :

"Sesungguhnya telah ada pada (diri) Rasulullah itu suri teladan yang baik bagimu (yaitu) bagi orang yang mengharap (rahmat) Allah dan (kedatangan) hari kiamat dan dia banyak menyebut Allah”. (Depag RI,2005:420)

Dalam pembelajaran Pendidikan Agama Islam (PAI) yang menjadi tujuan utamanya adalah bagaimana nilai-nilai ajaran Islam yang diajarkan akan dapat tertanam dalam diri siswa sehingga terjadi perubahan tingkah laku yang dilandasi dengan nilai-nilai ajaran Islam dalam kehidupan pribadinya maupun kehidupan sosial yang nantinya dapat berdampak pada terbentuknya "insan kamil”, bukan pemahaman bahwa proses pembelajaran PAI hanya sebagai proses "penyampaian pengetahuan tentang agama Islam" seperti yang terjadi selama ini.

Menurut Muhaimin (2004:75) dalam GBPP PAI di sekolah umum, dijelaskan bahwa Pendidikan Agama Islam adalah usaha sadar untuk menyiapkan siswa dalam meyakini, memahami, menghayati, dan mengamalkan agama Islam melalui kegiatan bimbingan, pengajaran, dan atau latihan dengan memperhatikan tuntutan untuk menghormati agama lain dalam hubungan kerukunan antar umat beragama dalam masyarakat untuk mewujudkan persatuan nasional.

Dari pengertian di atas dapat ditemukan beberapa hal yang perlu diperhatikan dalam pembelajaran Pendidikan Agama Islam, salah satunya adalah kegiatan (pembelajaran) Pendidikan Agama Islam diarahkan untuk meningkatkan keyakinan, pemahaman, penghayatan, dan pengamalan ajaran agama Islam dari siswa, yang di samping untuk membentuk kesalehan atau kualitas pribadi, juga sekaligus membentuk kesalehan sosial.

Pembelajaran atau ungkapan yang lebih dikenal sebelumnya "pengajaran" adalah upaya untuk membelajarkan siswa. Menurut Ahmad Zayadi dan Abdul Majid (2005:8) "Istilah pembelajaran (instruction) bermakna sebagai upaya untuk membelajarkan seseorang atau kelompok orang melalui berbagai upaya (effort) dan 
berbagai strategi, metode, pendekatan ke arah pencapaian tujuan yang telah direncanakan".

Menurut Muhaimin (2004:183), pembelajaran Pendidikan Agama Islam adalah suatu upaya membuat siswa dapat belajar, butuh belajar, terdorong belajar, mau belajar, dan tertarik untuk terus-menerus mempelajari agama Islam, baik untuk kepentingan mengetahui bagaimana cara beragama yang benar maupun mempelajari agama Islam sebagai pengetahuan. Istilah pembelajaran lebih tepat digunakan karena ia menggambarkan upaya untuk membangkitkan prakarsa belajar seseorang. Di samping itu, ungkapan pembelajaran memiliki makna yang lebih dalam untuk mengungkapkan hakikat desain pembelajaran dalam upaya membelajarkan siswa

Akan tetapi dalam pelaksanaannya, pembelajaran Pendidikan Agama Islam di sekolah yang dimaksudkan masih menuai kritik terhadap kesenjangan antara teori dan praktek yang terjadi. Salah satu kritikan disampaikan oleh Mochtar Buchori yang menilai kegagalan pendidikan agama disebabkan praktik pendidikannya hanya memperhatikan aspek kognitif semata dari pertumbuhan kesadaran nilai-nilai (agama) dan mengabaikan pembinaan aspek afektif dan konatifvolutif, yakni kemauan tekad untuk mengamalkan nilai-nilai ajaran agama. Dengan kata lain, pendidikan agama lebih berorientasi pada belajar tentang agama dan kurang berorientasi pada belajar bagaimana cara beragama yang benar. Akibatnya, terjadi kesenjangan antara pengetahuan dan pengamalan, antara gnosis dan praxis dalam kehidupan nilai agama, sehingga tidak mampu membentuk pribadi-pribadi Islami (Muhaimin,2004:88-89). Towaf juga menyebutkan pendekatan pembelajaran Pendidikan Agama Islam masih bersifat normatif, dalam arti pendidikan agama menyajikan norma-norma yang seringkali tanpa ilustrasi konteks sosial budaya sehingga siswa kurang menghayati nilai-nilai agama sebagai nilai yang hidup dalam keseharian. Selain itu, metodologi pendidikan agama tidak kunjung berubah sejak dulu hingga sekarang, padahal masyarakat yang dihadapi sudah banyak mengalami perubahan (Muhaimin,2004:106).

Menurut Trianto (2008:3), masalah pokok dalam pembelajaran formal (sekolah) dewasa ini adalah masih rendahnya daya serap siswa. Hal ini nampak dari prestasi belajar siswa yang senantiasa masih sangat memperhatikan. Prestasi ini 
tentunya merupakan hasil kondisi pembelajaran yang masih bersifat konvensional dan tidak menyentuh ranah dimensi siswa itu sendiri, yaitu bagaimana sebenarnya belajar itu (belajar untuk belajar). Dalam arti yang lebih substansial, bahwa proses pembelajaran hingga dewasa ini masih memberikan dominasi guru dan tidak memberikan akses bagi siswa untuk berkembang secara mandiri melalui penemuan dan proses berpikirnya.

Pembelajaran konvensional yang disebut-sebut sebagai penyebab rendahnya prestasi belajar siswa ini juga menjadikan suasana kelas cenderung teacher centered sehingga siswa menjadi pasif (Trianto,2008:4). Hal ini tentu saja banyak kita jumpai dalam pembelajaran Pendidikan Agama Islam di kelas selama ini. Meskipun demikian guru lebih suka menerapkan model tersebut, sebab tidak memerlukan alat dan bahan praktik, cukup menjelaskan konsep-konsep yang ada pada buku ajar atau referensi lain. Dalam hal ini siswa tidak diajarkan strategi belajar yang dapat memahami bagaimana belajar, berpikir, dan memotivasi diri sendiri.

Kritikan terhadap pembelajaran konvensional juga ditujukan pada cara guru mengajar yang terlalu menekankan pada penguasaan sejumlah informasi atau konsep belaka. Penumpukan informasi atau konsep pada siswa dapat saja kurang bermanfaat bahkan tidak bermanfaat sama sekali kalau hal tersebut hanya dikomunikasikan oleh guru kepada siswa melalui satu arah seperti menuang air ke dalam sebuah gelas. Tidak dapat disangkal bahwa konsep merupakan suatu hal yang sangat penting, namun bukan terletak pada konsep itu sendiri, tetapi terletak pada bagaimana konsep itu dipahami oleh siswa. Pentingnya pemahaman konsep dalam proses belajar mengajar sangat mempengaruhi sikap, keputusan, dan cara-cara memecahkan masalah. Untuk itu yang terpenting adalah terjadinya belajar yang bermakna dan tidak hanya seperti menuang air dalam gelas pada siswa (Trianto,2008:4-5).

Menurut Conny Setiawan (1992:8), dari sejumlah fenomena yang telah dikemukakan, maka dapat disinyalir bahwa ada "benang merah" yang melatarbelakangi cara mengajar guru tersebut. Para guru pada umumnya menerapkan cara mengajar yang mereka alami di lembaga pendidikan guru. Di lembaga pendidikan guru dulu, mereka harus menguasai terlalu banyak materi pelajaran yang 
terpisah-pisah dalam beberapa gugus. Praktek mengajar dipisahkan dari pelajaran teori, dan praktek itu sendiri terkadang dilaksanakan hanya untuk memenuhi persyaratan. Staf pengajar lembaga pendidikan guru pun tidak dapat dipersalahkan semuanya. Mereka hanyalah menerapkan cara mengajar yang mereka alami dari para guru atau dosen lembaga pendidikan tenaga kependidikan.

Berdasarkan alasan tersebut, maka sangatlah urgen bagi pendidik khususnya guru memahami karakteristik materi, siswa dan metodologi pembelajaran dalam proses pembelajaran terutama berkaitan pemilihan terhadap model-model pembelajaran modern. Dengan demikian proses pembelajaran akan lebih variatif, inovatif dan konstruktif dalam merekonstruksi wawasan pengetahuan dan implementasinya sehingga dapat meningkatkan aktifitas dan kreativitas siswa (Trianto,2008:8).

Untuk mengetahui apakah pembelajaran itu efektif atau efisien, dapat diketahui melalui kegiatan pembelajaran. Untuk itu pengajar dalam melaksanakan kegiatan pembelajaran seyogyanya tahu bagaimana membuat kegiatan pembelajaran berjalan dengan baik dan dapat mencapai tujuan pembelajaran yang diharapkan. Ciri utama kegiatan pembelajaran adalah adanya interaksi. Interaksi yang terjadi antara siswa dengan lingkungan belajarnya, baik dengan guru, teman-temannya, tutor, media pembelajaran, dan sumber-sumber belajar lainnya. Ciri lain dari pembelajaran adalah merupakan suatu sistem, yang di dalamnya terdapat komponen-komponen sebagai berikut: tujuan, materi / bahan ajar, metode pengajaran, media, evaluasi, siswa dan guru. Dengan demikian Peningkatan aktifitas dan kreativitas tersebut berarti pula peningkatan kualitas proses belajar dan bisa berlanjut pada peningkatan hasil belajar atau prestasi siswa.

Persoalan sekarang adalah bagaimana menemukan cara yang terbaik untuk menyampaikan berbagai konsep Pendidikan Agama Islam yang diajarkan sehingga siswa dapat menggunakan dan mengingat lebih lama konsep tersebut. Bagaimana guru dapat berkomunikasi baik dengan siswanya. Bagaimana guru dapat membuka wawasan berpikir yang beragam dari seluruh siswa sehingga dapat mempelajari 
berbagai konsep dan cara mengaitkannya dalam kehidupan nyata. Bagaimana guru dapat meningkatkan aktifitas proses belajar dan prestasi siswa sebagai hasil belajarnya.

Untuk membantu siswa memahami konsep Pendidikan Agama Islam dan memudahkan guru dalam mengajarkan konsep-konsep tersebut diperlukan suatu pendekatan pembelajaran yang langsung mengaitkan materi konsep pelajaran agama Islam dengan pengalaman nyata dalam kehidupan sehari-hari. Dengan pendekatan itu pula kualitas hasil (prestasi) belajar siswa diharapkan bisa meningkat. Pendekatan pembelajaran tersebut adalah pembelajaran kontekstual atau Contextual Teaching and Learning (CTL).

Pembelajaran kontekstual yang biasa disebut CTL (contextual teaching and learning) merupakan salah satu unit dari metode pembelajaran yang ada. Pembelajaran CTL didasarkan pada hasil penelitian (John Dewey, 1916) yang menyimpulkan bahwa "Siswa akan belajar dengan baik jika apa yang dipelajari terkait dengan apa yang telah diketahui dan dengan kegiatan atau peristiwa yang akan terjadi di sekelilingnya". Menurut Badruzaman (2006). "Pembelajaran ini menekankan pada daya pikir yang tinggi, transfer ilmu pengetahuan, mengumpulkan dan menganalisis data, memecahkan masalah-masalah tertentu baik secara individu maupun kelompok".

Jawahir (2005) mengemukakan bahwa guru PAI dapat menggunakan strategi pembelajaran CTL dengan memperhatikan beberapa hal sebagai berikut, yaitu: a) memberikan kegiatan yang bervariasi sehingga dapat melayani perbedaan individual siswa; b) lebih mengaktifkan siswa dan guru; c) mendorong berkembangnya kemampuan baru; d) menimbulkan jalinan kegiatan belajar di sekolah, rumah dan lingkungan masyarakat.

Dalam pembelajaran kontekstual, siswa diberi kesempatan untuk membangun pengetahuannya sendiri atau membangun gagasan-gagasan baru dan memperbaharui gagasan lama yang sudah ada pada struktur kognitif. Di samping itu menurut A. Saepul Hamdani (2003: 3) siswa juga diberi kesempatan untuk mencari dan menemukan sendiri pengetahuannya, melakukan observasi dan melakukan pemecahan masalah secara bersama-sama dalam kerangka kegiatan ilmiah, dan juga 
siswa diberi kesempatan untuk melakukan abstraksi atau suatu proses pemaknaan kehidupan sehari-hari yang dirujukkan dengan teori atau contoh yang ada.

Adanya metode pembelajaran CTL ini diharapkan dapat memberikan pengaruh yang positif terhadap peningkatan prestasi belajar siswa. Hal tersebut terlihat dari konsep metode pendekatan yang menghubungkan kegiatan dan bahan ajar dengan situasi nyata, sehingga siswa menjadi lebih responsif dalam menggunakan pengetahuan dan keterampilan di kehidupan nyata sehingga memiliki motivasi tinggi untuk belajar yang pada akhirnya dapat meningkatkan prestasi belajar siswa.

\section{Metode}

Penelitian ini merupakan penelitian korelasi dengan pendekatan kuantitatif dengan variabel x Contextual Teaching and Learning dan variabel y prestasi belajar. Penelitian ini dilaksanakan di SDIT Insantama Banjar yang merupakan sekolah islam favorit di Kota Banjar. Adapun yang menjadi objek penelitian adalah kelas V SDIT Instama Banjar dengan populasi 23 orang yang terdiri dari 13 perempuan dan 10 lakilaki dimana semua populasi dijadikan sampel penelitian. Data primer pada penelitian ini berasal dari hasil observasi, wawancara, dan angket. Adapun data sekunder berasal dari literatur yang berkaitan dengan penelitian.

\section{Pembahasan}

Menurut pendapat Elaine B. Johnson (2007:19) yang merumuskan pengertian CTL sebagai berikut: "The CTL system is an educational process that aims to help students see meaning in the academic material they are studying by connecting academic subjects with the context of their daily lives, that is, with the context of their personal, social, and cultural circumstances". Artinya sistem CTL merupakan suatu proses pendidikan yang bertujuan membantu siswa melihat makna dalam bahan pelajaran yang mereka pelajari dengan cara menghubungkannya dengan konteks kehidupan mereka sehari-hari yaitu dengan konteks lingkungan pribadinya, sosialnya, dan kultur kesehariannya.

Hal senada diungkap pula oleh Nurhadi (Depdiknas, 2002:5) yang berpendapat bahwa pembelajaran konstektual adalah konsep belajar yang membantu 
guru mengaitkan antara materi dan mendorong siswa membuat hubungan antara pengetahuan yang dimilikinya dengan penerapannya dalam kehidupan mereka seharihari dengan melibatkan tujuh komponen utama pembelajaran efektif, yakni konstruktivisme, bertanya, menemukan, masyarakat belajar, permodelan dan penilaian sebenarnya.

Selanjutnya menurut Wina Sanjaya (2006: 107) Contextual Teaching and Learning (CTL) adalah suatu pendekatan pembelajaran yang menekankan kepada proses keterlibatan siswa secara penuh untuk dapat menemukan materi yang dipelajari dan menghubungkannya dengan situasi kehidupan nyata sehingga mendorong siswa untuk dapat menerapkannya dalam kehidupan mereka. Dengan demikian, kegiatan pembelajaran akan lebih konkret, lebih realistik, lebih aktual, lebih nyata, lebih menyenangkan, dan lebih bermakna.

Maka pembelajaran kontekstual ini merupakan konsep belajar yang membantu guru mengaitkan antara materi yang diajarkan dengan situasi nyata siswa. Selain itu, pembelajaran kontekstual dapat mendorong siwa membuat hubungan antara pengetahuan yang dimilikinya dengan penerapannya dalam kehidupan seharihari mereka sebagai anggota keluarga dan masyarakat dengan melibatkan tujuh komponen utama pembelajaran efektif, yakni konstruktivisme, bertanya, menemukan, masyarakat belajar, permodelan dan penilaian sebenarnya. Tugas guru dalam kelas kontekstual ini adalah membantu siswa mencapai tujuannya, maksudnya guru lebih banyak berurusan dengan srtategi dari pada memberi informasi. Tugas guru mengelola kelas sabagai sebuah tim yang bekerja sama untuk menemukan suatu yang baru bagi siswa.

Pendekatan kontekstual perlu diterapkan mengingat bahwa sejauh ini pendidikan masih didominasi oleh pandangan bahwa pengetahuan sebagai perangkat fakta-fakta yang harus dihafal. Dalam hal ini fungsi fungsi dan peranan guru masih dominan sehingga siswa menjadi pasif dan tidak kreatif. Melalui pendekatan kontekstual ini siswa diharapkan belajar dengan cara mengalami sendiri bukan dengan cara menghafal 


\section{Kualifikasi Data}

SDIT Insantama Banjar yang merupakan sekolah SDIT favorit di Kota Banjar, Jawa Barat ini memiliki siswa dengan beraneka ragam kondisi, baik itu dilihat dari segi ekonomi, latar belakang keluarga, pendidikan keluarga, maupun yang lainnya. Dengan beragam latar belakang itulah, maka pola interaksi anak di sekolah cukup bervariasi. Berikut ini adalah tabel keadaan murid SDIT Insantama Banjar:

\section{Daftar Keadaan Siswa SDIT Insantama Banjar}

\begin{tabular}{|c|c|c|c|}
\hline Kelas & Juli & Agustus & September \\
\hline I & 50 & 49 & 48 \\
\hline II & 26 & 26 & 26 \\
\hline III & 39 & 39 & 39 \\
\hline IV & 39 & 39 & 38 \\
\hline V & 24 & 24 & 14 \\
\hline VI & 14 & 14 & $\mathbf{1 8 8}$ \\
\hline Jumlah & $\mathbf{1 9 2}$ & $\mathbf{1 9 1}$ & \\
\hline
\end{tabular}

Tujuan penelitian ini adalah untuk mengetahui seberapa besar pengaruh metode pembelajaran Contextual Teaching and Learning (CTL) terhadap prestasi siswa terhadap bidang stadi Pendidikan Agama Islam, pelaksanaan ini dilaksanakan di SDIT Insantama Banjar. Dengan ini di identifikasikan bahwa metode pembelajaran Contextual Teaching and Learning (CTL) dinamakan sebagai variabel X sedangkan prestasi belajar PAI dinamakan sebagai variabel Y. Umumnya prestasi belajar di sekolah berbentuk pemberian nilai ( angka) dari guru kepada siswa sebagai indikasi 
sejauh mana siswa telah menguasai materi pelajaran yang telah disampaikan, biasanya dinyatakan dengan angka, huruf, atau kalimat yang dihimpun dalam buku rapot:

\begin{tabular}{|c|c|c|c|}
\hline $\begin{array}{l}\text { Nilai } 10 \\
\text { cukup }\end{array}$ & : Istimewa & Nilai 5 & Hampir \\
\hline Nilai 9 & : Baik sekali & Nilai 4 & : Kurang \\
\hline Nilai 8 & : Baik & Nilai 3 & : Kurang sekali \\
\hline Nilai 7 & : Lebih dari cukup & Nilai 2 & : Buruk \\
\hline Nilai 6 & : Cukup & Nilai 1 & : Buruk sekali \\
\hline
\end{tabular}

Keterangan nilai dengan huruf :
A : Baik sekali
B : Baik
C : Cukup
D : Kurang
(Buku rapot SDIT Insantama Banjar)

Data-data penelitian tentang penerapan metode pembelajaran Contextual Teaching and Learning (CTL) dalam meningkatkan prestasi belajar PAI ini diperoleh melalui observasi, wawancara,angket dan dokumentasi.

1. Observasi, peneliti melakukan pengamatan dan mencatat data-data meliputi:
a. Prestasi belajar Pendidikan Agama Islam (PAI)
b. Keadaan guru dan siswa di SDIT Insantama Banjar
c. Struktur organisasi di SDIT Insantama Banjar 
2. Wawancara, peneliti melakukan interview kepada kepala sekolah SDIT Insantama Banjar dan guru Pendidikan Agama Islam.

3. Angket, peneliti menyebarkan pernyataan tertulis kepada siswa kelas V SDIT Insantama Banjar yang berjumlah 23 orang. Angket ini berisikan pertanyaanpertanyaan yang arus dijawab dengan cara memilih alternatif jawaban yang dianggap tepat menurut responden. Penyusun membuat angket metode pembelajaran Contextual Teaching and Learning (CTL) dalam meningkatkan prestasi terdiri dari 15 item dengan perincian sebagai berikut:

Kisi-Kisi Angket Metode Pembelajaran CTL

\begin{tabular}{|c|c|c|c|c|c|}
\hline \multirow{2}{*}{ No } & \multirow{2}{*}{ Indikator } & \multirow{2}{*}{ Nomor Item } & \multicolumn{2}{|c|}{ Jenis } & \multirow[t]{2}{*}{ Jumlah } \\
\hline & & & Positif & Negatif & \\
\hline 1. & $\begin{array}{l}\text { Perilaku dibangun atas } \\
\text { kesadaran diri. }\end{array}$ & $\begin{array}{c}1,2,3,4,9,11,12, \\
13,14,15\end{array}$ & $\begin{array}{c}1,2,4, \\
9,12,13,14\end{array}$ & $3,11,15$ & 10 \\
\hline 2 & $\begin{array}{l}\text { Siswa belajar dari teman } \\
\text { melalui kerja kelompok, } \\
\text { diskusi, saling mengoreksi }\end{array}$ & $5,6,8$ & 6,8 & 5 & 3 \\
\hline 3 & $\begin{array}{l}\text { Pembelajaran dikaitkan } \\
\text { dengan kehidupan nyata } \\
\text { atau masalah yang } \\
\text { disimulasikan. }\end{array}$ & 7,10 & 10 & 7 & 2 \\
\hline
\end{tabular}

Teknik analisa selanjutanya adalah scoring, untuk menetukan scoring semua pertanyaan dan pernyataan setiap itemnya dengan bobot nilai untuk setiap jawaban sebagai berikut: 
Skor item Alternatif Jawaban Responden

\begin{tabular}{|c|c|c|c|}
\hline \multicolumn{2}{|c|}{ Positif (+) } & \multicolumn{2}{c|}{ Negatif (-) } \\
\hline Jawaban & Skor & Jawaban & 1 \\
\hline Ya & 3 & Ya & 2 \\
\hline Kadang-kadang & 2 & Kadang-kadang & 3 \\
\hline Tidak & 1 & Tidak & \\
\hline
\end{tabular}

\section{Analisis Data}

Analisis ini digunakan untuk mengetahui tentang realitas penerapan metode pembelajaran Contextual Teaching and Learning (CTL) terhadap prestasi belajar PAI siswa SDIT Insantama Banjar. Adapun langkah-langkahnya sebagai berikut :

1. Uji Normalitas

Untuk keperluan pengujian normalitas data, dilakukan dengan dua cara yaitu dibuat histogram untuk distribusi standardized residual, dan dibuat grafik Normal Probability Plot pada setiap model. Untuk memperoleh hasil yang akurat, perhitungan dilakukan dengan bantuan komputer program SPSS, hasilnya peneliti kemukakan sebagai berikut ini: 


\section{Histogram}

Dependent Variable: Prestasi Belajar

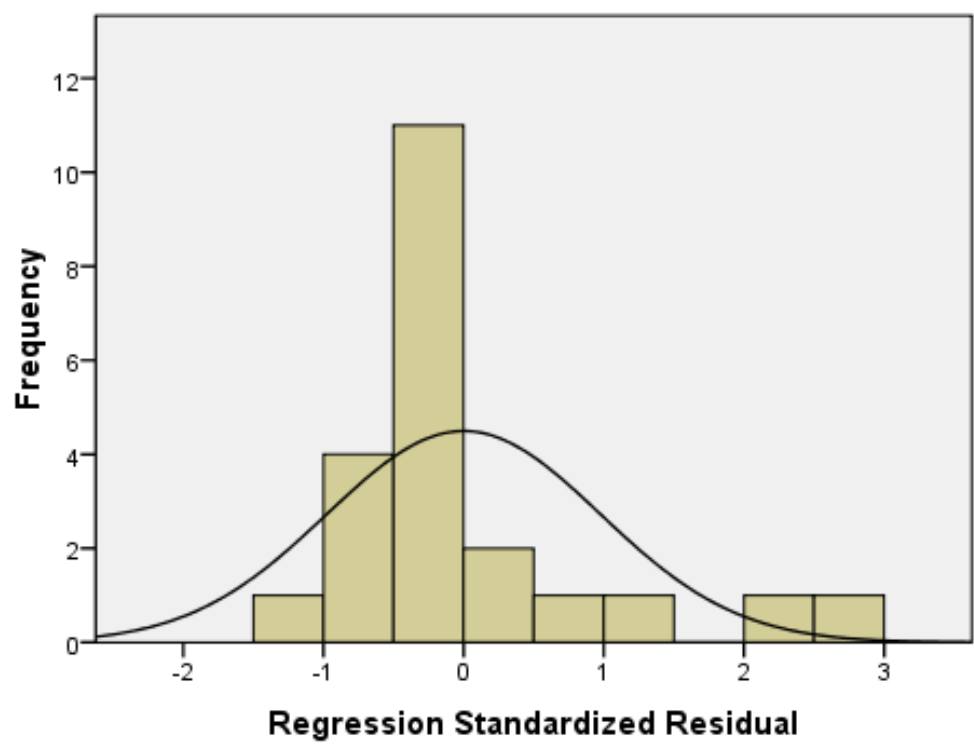

Mean $=6.77 \mathrm{E}-16$ Std. Dev. $=0.976$

Gambar diatas memperlihatkan adanya distribusi residual yang mempunyai kecenderungan sebaran normal

2. Perhitungan Koefisien Korelasi/Hubungan

\section{Model Summary ${ }^{\mathrm{b}}$}

\begin{tabular}{|l|r|r|r|r|}
\hline Model & \multicolumn{1}{|c|}{$\mathrm{R}$} & R Square & Adjusted R Square & Std. Error of the Estimate \\
\hline 1 & $.775^{\mathrm{a}}$ & .601 & .581 & 5.24572 \\
\hline
\end{tabular}

a. Predictors: (Constant), Metode Pembelajaran CTL

b. Dependent Variable: Prestasi Belajar

Berdasarkan tabel diatas terlihat nilai $\mathrm{r}$ sebesar 0,775 yang berarti metode pembelajaran CTL mempunyai pengaruh yang kuat terhadap prestasi belajar 
siswa. Selanjutnya nilai Koefisien Determinasi (r square) sebesar 0,601 yang berarti metode pembelajaran CTL mempunyai pengaruh sebesar 60,1\% terhadap prestasi belajar siswa

3. Signifikasi Hasil Korelasi

\section{Coefficients $^{\mathrm{a}}$}

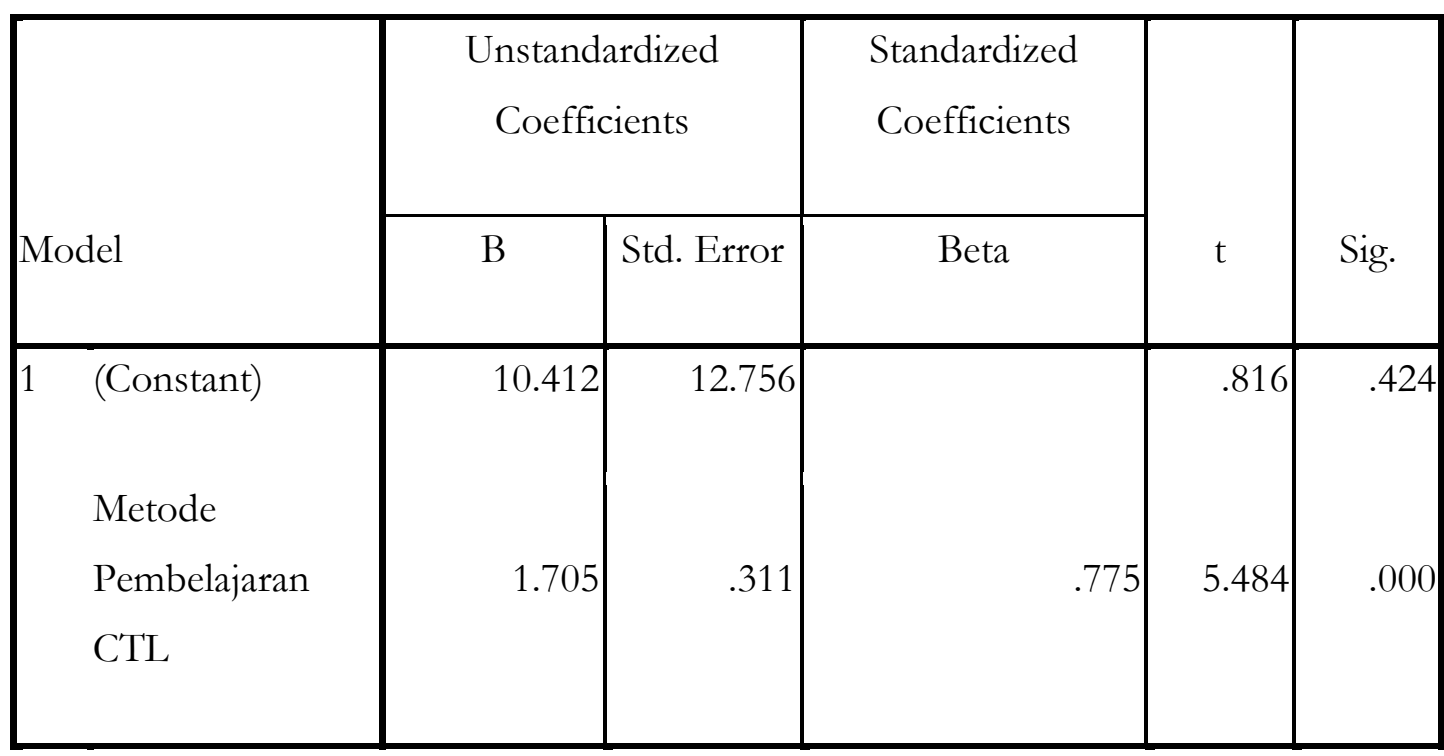

a. Dependent Variable: Prestasi Belajar

Berdasarkan tabel diatas terlihat nilai $\mathrm{t}$ hitung sebesar 5,484 yang berarti $>\mathrm{t}$ tabel $(1,72)$ sehingga dapata dikatakan terdapat pengaruh yang signifikan metode pembelajaran CTL terhadap prestasi belajar siswa.

4. Analisis Regresi

\section{Coefficients $^{\mathrm{a}}$}

\begin{tabular}{|l|c|c|c|c|c|}
\hline & \multicolumn{2}{|c|}{$\begin{array}{c}\text { Unstandardized } \\
\text { Coefficients }\end{array}$} & $\begin{array}{c}\text { Standardized } \\
\text { Coefficients }\end{array}$ & & \\
\cline { 2 - 5 } Model & B & Std. Error & Beta & $\mathrm{t}$ & Sig. \\
\hline
\end{tabular}




\begin{tabular}{|l|r|r|r|r|r|}
\hline 1. (Constant) & 10.412 & 12.756 & .816 & .424 \\
Metode Pembelajaran & 1.705 & .311 & .775 & 5.484 & .000 \\
CTL & & & & \\
\hline
\end{tabular}

a. Dependent Variable: Prestasi Belajar

Berdasarkan tabel diatas terlihat bahwa terdapat pengaruh yang signifikan metode pembelajaran CTL terhadap prestasi belajar siswa dengan persamaan regresi:

$\mathrm{Y}=10.412+1.705 \mathrm{X}$

\section{KESIMPULAN}

Penerapan metode pembelajaran Contextual Teaching and Learning (CTL) dapat meningkatkan prestasi belajar Pendidikan Agama Islam (PAI) siswa kelas V SDIT Insantama. Prestasi belajar yang diraih oleh siswa kelas V SDIT menunjukan adanya pengaruh positif dengan diterapkannya metode pembelajaran Contextual Teaching and Learning (CTL). Hasil penelitian koefisien korelasi atau hubungan ternyata menunjukan adanya hubungan yang signifikan antara kedua variabel yang diteliti, diperoleh harga koefisien dan korelasi antara metode pembelajaran Contextual Teaching and Learning (CTL) dengan prestasi belajar bidang studi Pendidikan Agama Islam (PAI). Metode pembelajaran Contextual Teaching and Learning (CTL) mempunyai pengaruh yang kuat terhadap prestasi belajar siswa. Adapun Koefisien Determinasi $(r$ square) sebesar 0,601 yang berarti metode pembelajaran CTL mempunyai pengaruh sebesar 60,1\% terhadap prestasi belajar siswa Adanya pengaruh yang signifikan metode pembelajaran CTL terhadap prestasi belajar siswa dengan persamaan regresi $\mathrm{Y}=10.412+1.705 \mathrm{X}$ 


\section{DAFTAR PUSTAKA}

A. Saepul Hamdani, Nizamia: Jurnal Pendidikan dan Pemikiran Islam. Vol. 6. No. 20.

Ahmad Zayadi dan Abdul Majid, Tadzkirah, Pembelajaran Pendidikan Agama Islam (PAI)

Al-Qur'an dan Terjemahnya, Jakarta: Depag RI, 2010

Anwar, Qomari. Pendidikan Sebagai Karakter Budaya Bangsa.2003.Jakarta: UHAMKA Press

Asmani, Jamal. 2012. 7 Tips Aplikasi Pakem. Jogjakarta: Diva Press

Badruzaman, Ahmad. 2006. Strategi dan Pendekatan dalam Pembelajaran. Yogyakarta : Ar ruuz

Conny Setiawan, Pendekatan Keterampilan Proses (Jakarta: PT Gramedia, 1992),

Depdiknas. 2002. Pendekatan Konstektual (Contextual Teaching and Learning). Jakarta :

Jawahir, Mochamad. 2005. Teknik dan Strategi Pembelajaran. Bandung : Cendikia Press

Johnson, Elaine B. 2007. Contextual Teaching and Learning: what it is and why it's here to stay (terj.). Bandung: Penerbit MLC

Johnson, Elaine B. 2009. Contextual Teaching and Learning; Menjadikan Kegiatan Belajar Mengajar Mengasyikan dan Bermakna. Bandung: Penerbit MLC

Kamus Besar Bahasa Indonesia Edisi Ketiga, 2005

Muhaimin, dkk., Paradigma Pendidikan Islam, Upaya Mengefektifkan Pendidikan Agama Islam di Sekolah (Bandung: PT Remaja Rosdakarya, 2004).

Nurhadi dan A.G. Senduk (2003). Pembelajaran Kontekstual dan Penerapannya dalam KBK. Malang: UMPRESS

Nurhadi, dkk. 2002. Pembelajaran Kontekstual dan Penerapannya dalam KBK. Malang: Universitas Negeri Malang.

Poerwakatja, Soegarda. Ensiklopedia Pendidikan. 1982. Jakarta: Gunung Agung.

Rochiati Wiriaatmadja, Metode Penelitian Tindakan Kelas (Bandung: PT Remaja Rosdakarya,2007

Sanjaya, Wina. 2006. Pembelajaran dalam Implementasi Kurikulum Berbasis Kompetensi. Jakarta: Kencana

Sudjana, Nana. 2005. Dasar-Dasar Proses Belajar Mengajar. Bandung: Sinar Baru Algensindo

Suharsimi Arikunto, dkk., Penelitian Tindakan Kelas (Jakarta: Bumi Aksara, 2007)

Sumiati dan Asra. 2008. Metode Pembelajaran. Bandung: CV Wacana Prima

Surakhmad,Winarno. Pengantar Interaksi Belajar Mengajar.1998.Bandung: Tarsito.

Trianto, Mendesain Pembelajaran Kontekstual (Contextual Teaching and Learning) di Kelas Jakarta: Cerdas Pustaka Publisher, 2008. 
Fajar Farham Hikam \& Salma Karima

Wahidmurni, Penelitian Tindakan Kelas dari Teori Menuju Praktik Malang: UM Press, 2008.

Yrama Widya, 2008. Fak. Tarbiyah IAIN Sunan Ampel Surabaya.

Zainal Aqib, dkk, Penelitian Tindakan Kelas untuk Guru SMP, SMA, SMK Bandung: $\mathrm{CV}$

Zuhairini dan Abdul Ghafir. 2004. Metodologi Pembelajaran Pendidikan Agama Islam. Malang: UM Press. 